\title{
A Comparative Study of Agricultural Products Wholesale Markets in the Philippines and South Korea for Future Development Planning
}

Rustom Nono Gonzaga (Institute of International Research \& Development, KNU) Hwa Seok Hwang (Institute of International Research \& Development, KNU) Dong Hyun Shin (Kyungpook National University)

\begin{abstract}
The significance of the wholesale market institution is that it enables businesses to offer appropriate products, find sellers and buyers in one place, and provide real prices (that are also low) whenever required. This study explores the core features of two wholesale farmers' markets in the Philippines and in South Korea, such as management systems, marketing systems, promotion mechanisms, prices, and the products sold, with the aim
\end{abstract}

Author: Rustom Nono Gonzaga (Student, Institute of International Research \& Development, Kyungpook National University, The Philippines)(gonzagarustom18@gmail.com)

Co-author: Hwa Seok Hwang (Professor, Institute of International Research \& Development, Kyungpook National University, Republic of Korea)(hhs2129@knu.ac.kr)

Corresponding author: Dong Hyun Shin (Professor, College of Agriculture and Life Sciences, Kyungpook National University, Republic of Korea)(dhshin@knu.ac.kr)

(c) Copyright Korea International Cooperation Agency. This is an Open-Access article distributed under the terms of the Creative Commons Attribution Non-Commercial License (http://creativecommons.org/ licenses/by-nc/4.0/) which permits unrestricted non-commercial use, distribution, and reproduction in any medium, provided the original work is properly cited. 


\section{Abstract}

of revealing their main similarities and differences. This study further aims to establish a development strategy so that the results can be utilized for policymaking in other countries too, and suggest implications as well. Based on the findings, Daegu wholesale market is more established than Sentrong Pamilihan when it comes to its operation and market facilities, due to its long history and experience as well as government financial support. A set of key elements is recommended as a guide for future planning, development, and operations in both the wholesale markets. These include enhancing the efficiency of logistics through maintenance and improvement of facilities, strong knowledgeable management, grading, packaging and branding programs, and innovative technologies.

Key words: Wholesale Market, Cold Storage Facility, Product Quality, Parking System, Auction 


\section{I .INTRODUCTION}

Agricultural Products Wholesale Market (APWM) is a unique market institution that organizes wholesale trade through the regulation, maintenance, and issuance of specialized space for displaying and selling agricultural products and other consumer goods. It also offers additional services such as storage of goods, processing, packaging and other services related to handling and transportation. When it comes to the importance of the APWMs as a distribution channel, their role is becoming more and more critical in developing the market. However, their competitiveness concerning various types of market centres must have a profiled strategy of competitive advantage.

The Department of Agriculture, Philippines conceived the Agri-Pinoy Trading Center (APTC)1) as an alternative marketing system and business model. It is co-owned, operated and controlled by small farmers through their cooperative or association, with strong support from the host local government units, and the government financial institutions as partners. Through APTC, the marketing system dominated by layers of traders, manipulation of production areas which are root of previous problems of APWMs in the Philippines were addressed. It is designed to address the problem of agricultural distribution or marketing by establishing a direct linkage between the farmers (producers) and buyers (consumers), making food plentiful and affordable while reducing trading layers, increasing producers' income, and stabilizing consumer prices. Farmers would then enter into the world of business in the context of an entrepreneurial perspective (Implementing Guidelines for the APTC Program, 2014).

Similarly, the Korean agricultural sector also faces several challenges to solve despite its rapid economic development. The Korean government has made extensive efforts to support the agricultural sector through various policy measures to tackle the challenges to be solved. In 2013, the South Korea

1) Agri-Pinoy Trading Center (APTC) or Sentro - is a wholesale market or trading facility where farmers, fishers and animal raisers can directly sell their marketable produce at prices determined through an open bidding process and where food processors and market vendors can procure their stocks, in cash, at the desired quality and at reasonable prices. To date, there are twenty-two APTCs in different stages of development in various parts in the Philippines (Department of Agriculture-Agribusiness and Marketing Assistance Services). 
Ministry of Agriculture, Food and Rural Affairs (MAFRA, 2013) announced a Distribution System Improvement Plan for Agricultural Products. One of the main strategies of agricultural distribution system improvement project is the wholesale market efficiency improvement. In 2017, the new government made the five-year (2018-2022) development plan for agriculture, rural community, and food industry to improve the agricultural competitiveness, increase the farmers' income, and enhance the quality of life for rural areas and residents (Im, 2014). Concerning it, this study aims to determine and explore each core feature of two wholesale farmers' markets in the Philippines and South Korea, such as management systems, marketing system, promotion mechanisms, prices, and products sold to reveal their main similarities and differences. It could help to establish development strategy so that the results can be used effectively for policy processes of other countries, and can suggest implications to policymakers of those countries. This was done by examining the available studies that were identified through a descriptive, evaluative method, utilizing documentary analysis, and finally, put forward the countermeasures for the development.

The Daegu wholesale market in Daegu city, South Korea2) was selected for the comparative study because it was one of the largest wholesale markets in terms of volume of transaction among thirty-three (33) public agricultural wholesale markets according to the MAFRA. It plays an essential role in the distribution of agricultural products in the Gyeongsangbuk-do. In the case of the Philippines, the Sentrong Pamilihan3) is a model for the establishment of the Agri-Pinoy trading centres in the Philippines, with massive potential by adopting a useful strategy that is why the researcher selected it. It is a wholesale trading centre where the farmers of Quezon Province can directly market their products to traders and walk-in buyers. It is an effective farm-to-consumer food supply chain to reduce unnecessary trading layers from the point of production to distribution. It offers central depot, agricultural growing scheme, balanced fertilization farming, agricultural input, training, and transport extension.

2) The term Daegu wholesale market was used in this research as shorten term for Daegu Agricultural and Fishery Products Wholesale Market, which was also used by other researchers.

3) The term Sentrong Pamilihan was used in this research as shorten and local term for Sentrong Pamilihan ng Produktong Agrikultura sa Quezon Foundation Incorporated (SPPAQFI). 


\section{RESEARCH METHODOLOGY}

The researcher developed an interview guide and survey questionnaire to gather the data needed in the study. A combination of pretested questions from Estimating the Economic Impact of Public Markets (Econsult Corporation, 2007) and Producer-only Farmers' Markets in the Mid-Atlantic Region: A Survey of Market Managers Oberholtzer \& Grow (2003), and A Study on Development of New York City Wholesale Farmers' Markets (Market Ventures / Karp Resources, 2005) were adapted to develop a questionnaire. The researcher used two types of survey questionnaires, one questionnaire is for the customer, and the other one is for the market operator. Supplementary questions were developed in consultation with market officials.

The survey was conducted separately for four months since the setting of the study was located in two different countries. It was conducted in Sentrong Pamilihan last March to May 2020 and last July to August in Daegu wholesale market. A total of 60 survey questionnaires were completed for the customers' side and two survey questionnaires for the market operators on the two agricultural wholesale markets. The researcher hired two enumerators to conduct the survey in the Sentrong Pamilihan and personally surveyed in Daegu wholesale market. It was conducted via face to face interviews during the market hour from 6:00 am to 11:00 am, despite COVID-19, which became the reason why there was only a limited number of respondents who participated in the survey.

This study employed ANOVA (Analysis of Variance) tests to determine if significant differences existed between buyers visiting two wholesale markets. The researcher also used Cronbach's alpha test to measure the reliability of the questionnaire regarding customers' view on product quality by market. All the respondents' data for each market was compiled into a single database and was analyzed using Statistical Package for the Social Sciences (SPSS) software.

\section{LITERATURE REVIEW}

One of the advantages of a wholesale market is that it enables food procurement for public institutions at stock market prices without inviting 
tenders, thus leading to saving time and money. It also prevents unloyal competition and provides better conditions for market placement of local producers' products. With this, it makes encouragement for the cooperation development, and associations to create additional value for fresh food products (calibration and packing) (Vlahović, 2013). The construction of the wholesale market has real economic indicators as a public infrastructure object of urban and regional importance, as well as due to the constant interest of buyers for this type of trade, regardless of the increased presence of competing companies. With rapid urban growth in many parts of the world, wholesale markets will continue to play a vital role in channelling a wide range of products to urban consumers, despite the adoption of new techniques, such as the direct supply of supermarkets by farmers. Investments in the infrastructure of the wholesale markets will undoubtedly be increased over the years to come. However, wholesale markets will not be a financial burden for governments, whether local or national. If they are well managed, they can be led professionally and bring a strong stimulus to the modernization of the food market as a whole (Kuzman et al., 2017).

Efficiency is one of the most critical goals in agricultural and food marketing. It directly affects food security, particularly the economic and physical access to food of households. Efficient and effective flow of food from production point (farmers) to consumption point (consumers) can facilitate the availability, accessibility, and affordability of adequate food to consumers (Pabuayon et al., 2014). Marketing efficiency can benefit all the key actors in a market chain. Technically, an efficient marketing system is achieved when the resulting marketing costs (including losses) are minimized. The profits or returns of market intermediaries are reasonable. That is, the marketing margin is just enough to cover the costs of marketing services, and there are no unreasonable profits generated by the market intermediaries (Pabuayon et al., 2013).

When it comes to the importance of the wholesale market as a distribution channel, their role is becoming more and more critical in the development of the market. However, also their competitiveness in various types of market centres must have a profiled strategy of competitive advantage (Prdić, 2016). According to Kuzman et al. (2017), the distribution of agricultural products must 
be adapted to the changes in the market environment. The importance of the market for agricultural products as part of the overall product market takes a special place due to the specific nature of the production process in agriculture. The significance of the wholesale market is reflected in various activities related to the distribution and sale of agricultural products. A type of short supply chain can solve many problems concerning long-distance transport. Physical distance is reduced between the producer and the consumer. Furthermore, personal relationships and trust can also be established between these two actors. Also, it provides small producers with the opportunity to produce and sell local, high-quality foods, and consumers can enjoy delicious, mostly locally-sourced, organic food products (Gombkötő, 2018).

Distribution of agricultural products in Korea has been significantly transformed by the essential environmental changes at home and abroad and government's adaptation policies such as the establishment of public wholesale markets and implementation of auction transactions, structural improvement measures with 42 trillion won for the distribution service market due to free trade of agricultural products, the establishment of agricultural products processing centres nationwide, and revitalization of economic projects led by cooperatives. In particular, the government promotes diversification of distribution channels and competition between them with the master plan for improving distribution in 2013 (Im, 2013).

\section{COMPARISON OF TWO AGRICULTURAL PRODUCTS WHOLESALE MARKETS}

\section{Market Profile}

〈Table 1〉 shows the main features of two wholesale markets. The Daegu wholesale market (established in 1988), employed with 20,000 employees was more established compared to Sentrong Pamilihan (established in 2004) when it comes to the years of operation and size of the market. It was managed by the local administrative government while Sentrong Pamilihan was managed by a 
〈Table 1〉 Main features of two wholesale markets

\begin{tabular}{l|c|c}
\hline \multicolumn{1}{c|}{ Questions } & $\begin{array}{c}\text { Daegu wholesale market } \\
\text { South Korea }\end{array}$ & $\begin{array}{c}\text { Sentrong Pamilihan } \\
\text { Philippines }\end{array}$ \\
\hline Date of establishment & 1988 & 2004 \\
\hline Name of management & $\begin{array}{c}\text { Local administrative } \\
\text { government }\end{array}$ & Foundation \\
\hline Market area & 1.67 Hectare & 0.5 Hectare \\
\hline $\begin{array}{l}\text { Which of the following best describes } \\
\text { the area in which the market is located? }\end{array}$ & Urban & Sub-urban \\
\hline $\begin{array}{l}\text { How many other employees does the } \\
\text { market employ? }\end{array}$ & 20,000 employees & 32 full-time workers \\
\hline $\begin{array}{l}\text { What is the actual value for all product } \\
\text { sales at this market last 2019? }\end{array}$ & $\begin{array}{c}\text { Estimated amount of } \\
790.1 \text { Million USD. }\end{array}$ & $\begin{array}{c}\text { Estimated amount of } \\
3.1 \text { Million USD. }\end{array}$ \\
\hline $\begin{array}{l}\text { What is the actual value for annual } \\
\text { expenditures/spending last 2019? }\end{array}$ & $\begin{array}{c}\text { Estimated amount of } \\
4.2 \text { Million USD }\end{array}$ & $\begin{array}{c}\text { Estimated amount of } \\
196,000 \text { USD }\end{array}$ \\
\hline $\begin{array}{l}\text { What are the typical hours of operation } \\
\text { for the market? }\end{array}$ & 5 am - 6 pm & $\begin{array}{c}4-10 \text { am, and } \\
5 \text { pm-2 am }\end{array}$ \\
\hline \begin{tabular}{l} 
Daily average trading volume \\
\hline
\end{tabular} & 1,206 tons & 200 tons \\
\hline
\end{tabular}

foundation. That was why there was a high difference between their annual product sales with an estimated amount of 787 million USD and expenditures with an estimated difference amount of 4 million USD. The Deagu wholesale market operates between 5 am to $6 \mathrm{pm}$. In contrast, Sentrong Pamilihan market has two schedules: the first schedule was from 4 am to $10 \mathrm{am}$, the second schedule was from $5 \mathrm{pm}$ to $2 \mathrm{am}$. In the Sentrong Pamilihan, the estimated people attending every day were more than 1,000 customers while in the Daegu wholesale market estimated the number of vehicles visiting per day, which was around 13,000 vehicles.

There were 1,700 farmer vendors present in Sentrong Pamilihan with a daily average trading volume of 200 tons last 2019. The twenty percent or 40 tons came from more than 500 vegetable farmer-members, and 80 percent or 160 tons came from non-member farmers, especially the highland vegetables from Northern parts of the Philippines, mostly from Benguet province, Nueva Ecija, and Cabanatuan. The Daegu wholesale market on the otherhand was composed of Agricultural corporation (5 corporations), Agricultural middleman (315 
people), Fisheries corporation (3 corporations), Fisheries sellers (54 people), Livestock Corporate Company (1 corporation), Livestock sellers (20 people) Associated Merchant Operators (200 people). It was the main reason why they have a high daily average trading volume of 1,206 tons. Both wholesale markets have the same type of buyers which were institutional buyers, retailers, wholesalers, and food manufacturers.

The Sentrong Pamilihan is located in a sub-urban area whereas the Daegu wholesale market is located in an urban area. The Daegu wholesale market has a high average area $\left(\mathrm{m}^{2}\right)$ that is occupied per vendor, which is $35 \mathrm{~m}^{2}$ for the agricultural products compared to the $6 \mathrm{~m}^{2}$ in Sentrong Pamilihan. During peak season (June to December), where there are many buyers, in Sentrong Pamilihan, more than 1,000 vendors are present at the market and on lean season or summertime (April to May), there are more or less 500 vendors. In Daegu wholesale market, the peak season is from January to February with 1,600 vendors, and the lean season is from April to June with 1,200 vendors. In the Sentrong Pamilihan, vegetables, fruits, value-added non-food products, value-added food products are being sold at the market. In contrast, in Daegu wholesale market, their products are more focused on vegetables and fruits. The method of advertising in Sentrong Pamilihan is through social media like Facebook, whereas, in Daegu wholesale market, it is more on brochures and flyers.

In the Philippines, Sentrong Pamilihan has a processing plant, stock room, and a trading place where the selling and purchasing of vegetables and other merchandise take place. They also have a LINGKODSAKA, a place where organic and other agricultural supplies can be bought. Besides, their amenities/services provided to the public and vendors are restrooms, delivery service, function hall. In the case of Daegu wholesale market, they have available cold storage, warehouse as their facilities for postharvest activities, and auction area intended for agricultural products. They also have other facilities like mechanical and electrical rooms, motel, restaurant, coffee shop, and convenience store.

When it comes to the auction market, auctions of each item in the Daegu wholesale market are operated at each different time (fruits: 6:00 am, leaf vegetables: 9:00 am, food crops and other vegetables: 3:00 pm, mushroom: 4:00 
pm). Daegu wholesale market is a public wholesale market that is why the auction market is operated and managed fairly by a management office to supply safe and sound agricultural products to people while in Sentrong Pamilihan, the auction market is not a regular basis. It only happens in some agricultural products with low supply but high in demand and facilitated by an in-house marketer who is responsible for the selling of vegetables and other merchandise in the market.

\section{Wholesale Market Distribution Flow}

\section{1) Sentrong Pamilihan}

Two Distribution flows are present in Sentrong Pamilihan which are available for the member and non-member farmers (〈Figure 1〉). For the member farmers, there is also an option if they want to transport their products via the pick-up (P.U.) process of Sentrong Pamilihan or self-deliver. (S.D.) process. The difference for this process is only upon arrival at the Sentrong Pamilihan because for the P.U. process, the market helper will unload the commodities straight to the trading centre while for the S.D. process, the farmer will hire a porter that will help them to unload the commodities to the trading centre. Open bidding process happens in Sentrong Pamilihan and it involves both P.U. and S.D. During bidding, the negotiating marketer sets the price and facilitates the

\section{〈Figure 1〉 Sentrong Pamilihan distribution flow}

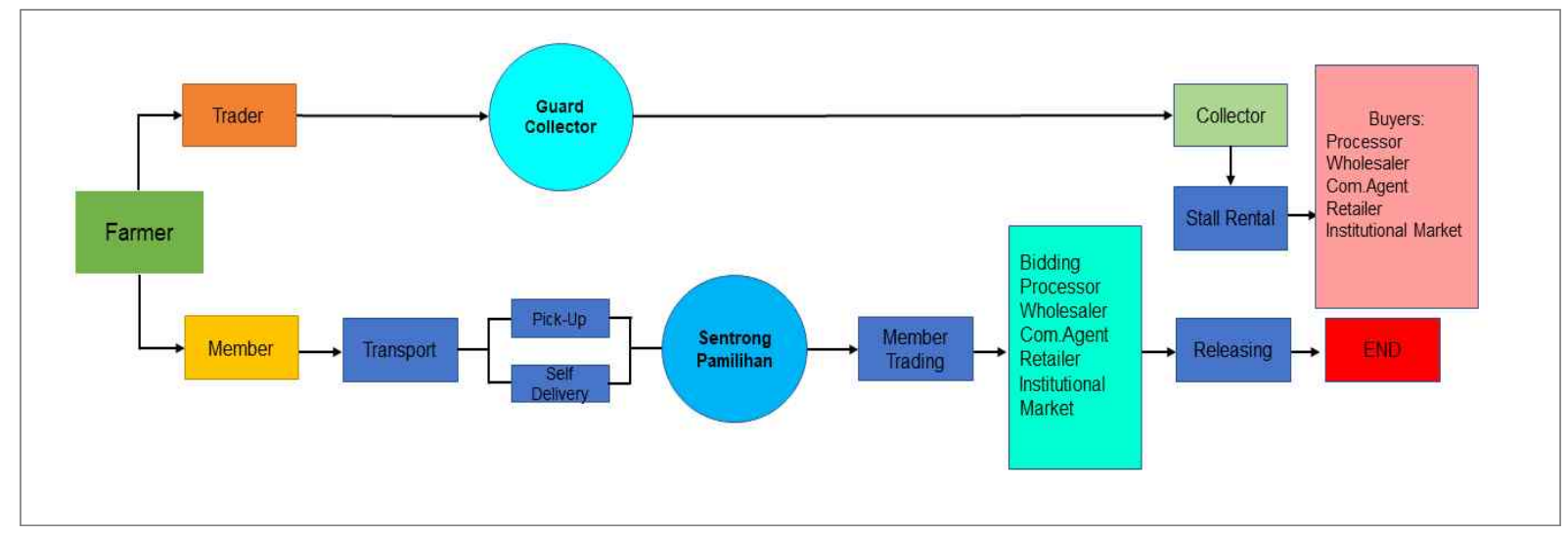

Source: Sentrong Pamilihan Ng Produktong Agrikultura sa Quezon Operations manual, 2014. 
trading of the product. The system marketer will encode the list in the handy terminal and will issue a withdrawal ticket to the individual trader. The withdrawal ticket bears the name of the trader, the commodity, and the volume purchased. The price agreed upon per commodity grade, farmer's name, the total amount to be paid by the buyer, and the name of the system marketer. The buyer will get the withdrawal ticket from the system marketer and will proceed to the cashier for payment. The system marketer will approve the release of commodities by attaching a sticker on the bag bearing the signature of the marketer who released the commodities. The security guard will check all out-going commodities to make sure that they have stickers as proof that the commodities are cleared for release. The system marketer will then request the accounting department to print the summary of all transaction details posted at the E-Support Link (ESL) System.4) The report contains the total volume delivered by farmers, the volume traded, and the remaining volume of commodities.

Non-member farmers/traders are also allowed to sell their produce in a designated area at the Sentro Pamilihan where they do their marketing or trading activities. They pay an entrance fee of Php 0.25 or 0.0051 USD per kilo of produce for the use of the centre. An additional rental fee of Php20 to Php30 or 0.42 to 0.62 USD per day is charged for the use of a stall ( $2 \mathrm{sqm} \times 2 \mathrm{sqm}$ ). In case the trader does not operate for three days, the management should be informed ahead of time; otherwise, the stall will be given to other interested traders. The operation of non-member traders supports the over-all viability of the Sentro Pamilihan through the provision of commodities not produced by the farmers supplying the Sentro Pamilihan

\section{2) Daegu wholesale market}

〈Figure 2〉 shows the Daegu wholesale market distribution flow. Local as-

4) E-Support Link System (ESL) - is an electronic sales management system which uses code mechanism for recording purchase and sales transactions in an efficient, secure and convenient manner. This system was provided by the ESL Ltd. and piloted at Sentrong Pamilihan ng Produktong Agrikultura sa Quezon (SPPAQ) with the support of Japan International Cooperation Agency (JICA). 


\section{〈Figure 2〉 Daegu wholesale market distribution flow}

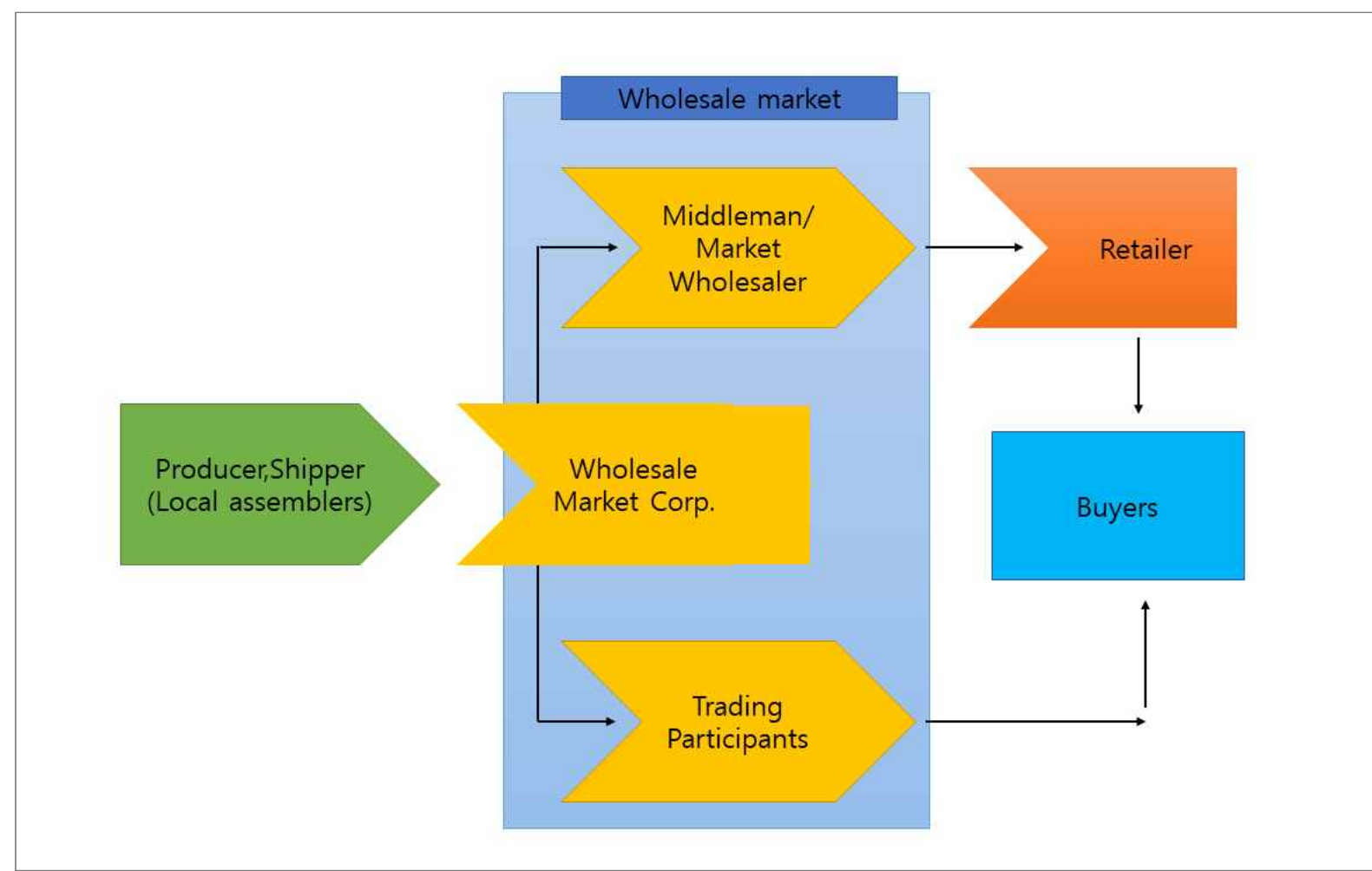

Source: Daegu agricultural and fishery wholesale market management.

semblers/shippers collect the agricultural and fishery products and ships them to the wholesale market. Immediately, wholesale market corporation (joint market) pay the meridian price to the shipper after the fair price is determined by collecting agricultural and fishery products from the production area. They are also responsible for the information transmission function to inform the market transaction status and receive a commission of $6 \%$ from the shipper. Wholesalers and middlemen purchase agricultural and fishery products listed on the wholesale market with permission from the founder of the wholesale market of agricultural and fishery products and sell it to the retailers, then the retailers sell that to consumers. On the other hand, massive consumers and retailers' associations are considered as trading participants who registered in the wholesale market management office. They participate in auctions, purchase listed agricultural and fishery products, and sell it directly to processors, exporters, consumer organizations, and other buyers(Daegu Metropolitan City, 2020).

In Daegu wholesale market, there are various forms of exchange, logistics, and composition functions: 
1. In the auction market, wholesale market corporations act as collectors, and the middlemen are the distributor. The wholesale market corporation is responsible for transferring ownership of agricultural products from the shipper to the middleman through the auction.

2. In the wholesale market, market wholesalers collect and distribute agricultural products at the same time. They sell agricultural products out of the market under pre-signed contracts. They also sell it to buyers who visit the market. Distribution functions include securing accounts, product displays, and various sales promotion activities performed by middlemen and market wholesalers for smooth sales activities.

3. Logistics functions such as storage and transportation that occur until the ownership of agricultural products are transferred to a middleman or market wholesaler are carried out at the responsibility of the shipper. Besides, logistics functions such as storage and transportation that occur after unloading to auction houses or market wholesalers are carried out at the responsibility of the middle seller or market wholesaler. The wholesale market is equipped with a variety of logistics facilities such as a low-temperature warehouse which helped revitalize the sales of middlemen and supply fresh agricultural products.

4. It can be seen as a distribution-making function performed by this wholesale market such as the standardization of packaging and grading, the immediate settlement of the shipment price of the wholesale market corporation, the loss compensation incurred when the shipment expresses dissatisfaction with the price of the shipment, and the provision of price information.

\section{Market Management}

Both markets have policies, rules, and restrictions on the sellers and the products they are selling at the market and the management team and farmers are always involved in the decision-making process regarding market operation. In Sentrong Pamilihan, 60\% of their financial support for the market comes from the public organization (farmers member) and $40 \%$ from vendors fee, 
while in Daegu wholesale market, financial supports to maintain the facilities are coming from the local government budget. Vegetables, fruits, value-added non-food products, and value-added food products are the common products that are being sold in Sentrong Pamilihan. In contrast, products in Daegu wholesale market are more focused on vegetables and fruits. Both wholesale markets sponsored workshops or offered special information. The difference is, the Sentrong Pamilihan offers workshops/special information that includes improving product quality and how to attract customers, whereas, in Daegu wholesale market, the information is more related to distribution (law, policy direction, support).

There is no serious rivalry between vendors in Sentrong Pamilihan whereas there is a slight problem in Daegu wholesale market. The major problem in Sentrong Pamilihan is managing the employees, especially the marketers dealing with other people implementing new policies. In Daegu wholesale market, the major problem is in the process of carrying out the facility modernization project between 2021 and 2023. There are also pending issues such as facility design and transportation traffic.

\section{Customer's Socio-Demographic Characteristics}

It can be gleaned from the $\langle$ Table 2$\rangle$ that, all respondents from both markets were responsible for deciding on purchasing products.. Daegu wholesale market has a greater percentage of male respondents (77\%), while Sentrong Pamilihan has a more significant percentage of female respondents (83\%). However, both markets have a greater percentage $(53 \%$ and $57 \%$ ) of the customer's age bracket from 45-64 years old. Maecheon Wholesale Market tended to draw a more significant percentage of the respondents with Bachelor's Degree (57\%) compared to Sentrong Pamilihan (47\%). All of the respondents (100\%) from Daegu wholesale market and almost all the respondents from the Sentrong Pamilihan (80\%) heard about the market by the word of mouth through their friends, relatives, vendors etc. All respondents from both markets were also responsible for deciding in purchasing products. In some cases, it shows that over half of customers from Daegu wholesale market (70\%) and Sentrong 
〈Table 2〉 Customers characteristic by market

\begin{tabular}{|c|c|c|c|c|}
\hline \multirow{2}{*}{$\begin{array}{l} \\
\begin{array}{l}\text { Person responsible for making } \\
\text { decisions about purchasing } \\
\text { products }\end{array}\end{array}$} & \multicolumn{2}{|c|}{$\begin{array}{l}\text { Daegu agricultural and } \\
\text { fishery products wholesale } \\
\text { market South Korea }\end{array}$} & \multicolumn{2}{|c|}{$\begin{array}{l}\text { Sentrong Pamilihan ng } \\
\text { Produktong Agrikultura sa } \\
\text { Quezon Foundation Inc. } \\
\text { (SPPAQFI) Philippines }\end{array}$} \\
\hline & Frequency & Percent (\%) & Frequency & Percent (\%) \\
\hline Yes & 30 & 100 & 30 & 100 \\
\hline No & 0 & 0 & 0 & 0 \\
\hline \multicolumn{5}{|l|}{ Gender } \\
\hline Male & 23 & 77 & 5 & 17 \\
\hline Female & 7 & 23 & 25 & 83 \\
\hline \multicolumn{5}{|l|}{ Age } \\
\hline $25-44$ & 14 & 47 & 13 & 43 \\
\hline $45-64$ & 16 & 53 & 17 & 57 \\
\hline \multicolumn{5}{|l|}{ Highest educational background } \\
\hline Bachelor's degree & 17 & 57 & 14 & 47 \\
\hline High school graduate & 13 & 43 & 11 & 37 \\
\hline Elementary graduate & 0 & 0 & 5 & 17 \\
\hline \multicolumn{5}{|l|}{ Heard about the market } \\
\hline $\begin{array}{l}\text { Word of mouth } \\
\text { (friends, relatives, vendors etc.) }\end{array}$ & 30 & 100 & 24 & 80 \\
\hline Social media & 0 & 0 & 6 & 20 \\
\hline \multicolumn{5}{|l|}{ Types of customers } \\
\hline $\begin{array}{l}\text { Institutional buyers } \\
\text { (hotel, caterer restaurant etc.) }\end{array}$ & 3 & 10 & 2 & 7 \\
\hline Retailers & 6 & 20 & 8 & 27 \\
\hline Wiolesale produce distributor & 21 & 70 & 20 & 67 \\
\hline
\end{tabular}

Pamilihan (67\%) are wholesale produce distributors.

\section{Price and Purchasing Behaviors}

〈Table 3〉 shows that majority of the customers in both wholesale markets visited the market every day (93\% Daegu wholesale market and 87\%: Sentrong Pamilihan), with the use of their personal vehicle and spent above 4 hours in purchasing products. The majority of the customers in Sentrong Pamilihan are 
〈Table 3〉 Purchasing behavior by market

\begin{tabular}{|c|c|c|c|c|}
\hline \multirow[b]{2}{*}{ Frequency of visits } & \multicolumn{2}{|c|}{$\begin{array}{l}\text { Daegu agricultural and } \\
\text { fishey products wholesale } \\
\text { market South Korea }\end{array}$} & \multicolumn{2}{|c|}{$\begin{array}{l}\text { Sentrong Paimlihan ng } \\
\text { Produktong Agrikultura sa } \\
\text { Quezon Foundation Inc. } \\
\text { (SPPAQFI) Philippines }\end{array}$} \\
\hline & Frequency & Percent (\%) & Frequency & Percent (\%) \\
\hline Every day & 28 & 93 & 26 & 87 \\
\hline Every week & 1 & 3 & 4 & 13 \\
\hline Occasional & 1 & 3 & 0 & 0 \\
\hline \multicolumn{5}{|l|}{ Time spent } \\
\hline $1-2$ hours & 3 & 10 & 0 & 0 \\
\hline 2-3 hours & 3 & 10 & 1 & 3 \\
\hline 3-4 hours & 2 & 7 & 3 & 10 \\
\hline above 4 hours & 22 & 73 & 26 & 87 \\
\hline \multicolumn{5}{|l|}{ Distance from market } \\
\hline $0-2 \mathrm{~km}$ & 10 & 33 & 22 & 73 \\
\hline $2-5 \mathrm{~km}$ & 8 & 27 & 1 & 3 \\
\hline 5-9 km & 7 & 23 & 0 & 0 \\
\hline $9-15 \mathrm{~km}$ & 5 & 17 & 0 & 0 \\
\hline Above 15 km & 0 & 0 & 7 & 23 \\
\hline \multicolumn{5}{|l|}{ Mode of transportation } \\
\hline Public transportation & 2 & 7 & 4 & 13 \\
\hline Personal vehicle & 24 & 80 & 26 & 87 \\
\hline Service truck & 4 & 13 & 0 & 0 \\
\hline \multicolumn{5}{|l|}{ Amount of money spent } \\
\hline Below $100 \$$ & 0 & 0 & 1 & 3 \\
\hline $101-200 \$$ & 5 & 17 & 2 & 7 \\
\hline $201-300 \$$ & 1 & 3 & 2 & 7 \\
\hline $301-500 \$$ & 0 & 0 & 3 & 10 \\
\hline $501-700 \$$ & 6 & 20 & 5 & 17 \\
\hline Above $700 \$$ & 18 & 60 & 17 & 57 \\
\hline \multicolumn{5}{|l|}{ Purchased products } \\
\hline Vegetables & 13 & 33 & 29 & 63 \\
\hline Fruits & 25 & 64 & 13 & 28 \\
\hline Processed non-food products & 1 & 3 & 0 & 0 \\
\hline Processed food products & 0 & 0 & 4 & 9 \\
\hline
\end{tabular}

near at the market with 0-2 km distance same as with the respondents in Daegu wholesale market. But based on the survey, Sentrong Pamilihan has the greater 
number of the respondents (73\%) who were near in the market place as compared to Daegu wholesale market with only $(33 \%)$ from the total number of the population involved in the study. It also shows that over half of the customers in Daegu wholesale market (60\%) and Sentrong Pamilihan (57\%) spent above $700 \$$ in purchasing market products. In terms of purchased products, customers from Daegu wholesale market purchased more on fruits with 64\% from the total number of the respondents whereas in Sentrong Pamilihan, 63\% of the respondents purchased more on vegetables.

\section{Statistical Analysis}

In $\langle$ Table 4$\rangle$, the statistical ANOVA test was used to determine if significant differences existed between customer characteristics and purchasing behaviours. Based on the table, there was only a statistically significant difference in the customers of Sentrong Pamilihan in terms of the time they spent on how much money they spent at the market with a 0.005 significance level. It means that

〈Table 4〉 One-way ANOVA significance values for customer characteristics and purchasing behavior

\begin{tabular}{|c|c|c|c|c|c|c|}
\hline \multicolumn{2}{|c|}{ Name of market } & $\begin{array}{l}\text { Sum of } \\
\text { squares }\end{array}$ & $\mathrm{df}$ & $\begin{array}{l}\text { Mean } \\
\text { square }\end{array}$ & F-value & Sig. \\
\hline \multicolumn{7}{|c|}{ Education by money spent } \\
\hline \multirow{3}{*}{$\begin{array}{c}\text { Daegu wholesale } \\
\text { market }\end{array}$} & Between groups & .389 & 3 & .130 & .483 & .697 \\
\hline & Within groups & 6.978 & 26 & .268 & & \\
\hline & Total & 7.367 & 29 & & & \\
\hline \multirow{3}{*}{ Sentrong Pamilihan } & Between groups & 4.571 & 5 & .914 & 1.870 & .137 \\
\hline & Within groups & 11.729 & 24 & .489 & & \\
\hline & Total & 16.300 & 29 & & & \\
\hline \multicolumn{7}{|c|}{ Gender by frequency of visits } \\
\hline \multirow{3}{*}{$\begin{array}{c}\text { Daegu wholesale } \\
\text { market }\end{array}$} & Between groups & .117 & 2 & .058 & .300 & .743 \\
\hline & Within groups & 5.250 & 27 & .194 & & \\
\hline & Total & 5.367 & 29 & & & \\
\hline \multirow{3}{*}{ Sentrong Pamilihan } & Between groups & .032 & 1 & .032 & 217 & .645 \\
\hline & Within groups & 4.135 & 28 & .148 & & \\
\hline & Total & 4.167 & 29 & & & \\
\hline
\end{tabular}




\section{〈Table 4〉 Continued}

\begin{tabular}{|c|c|c|c|c|c|c|}
\hline \multicolumn{2}{|c|}{ Name of market } & $\begin{array}{l}\text { Sum of } \\
\text { squares }\end{array}$ & df & $\begin{array}{l}\text { Mean } \\
\text { square }\end{array}$ & F-value & Sig. \\
\hline \multicolumn{7}{|c|}{ Time spent by money spent } \\
\hline \multirow{3}{*}{$\begin{array}{c}\text { Daegu wholesale } \\
\text { market }\end{array}$} & Between groups & 6.667 & 3 & 2.222 & 2.339 & .097 \\
\hline & Within groups & 24.700 & 26 & .950 & & \\
\hline & Total & 31.367 & 29 & & & \\
\hline \multirow{3}{*}{ Sentrong Pamilihan } & Between groups & 2.967 & 5 & .593 & 4.450 & .005 \\
\hline & Within groups & 3.200 & 24 & .133 & & \\
\hline & Total & 6.167 & 29 & & & \\
\hline \multicolumn{7}{|c|}{ Time spent by distance from market } \\
\hline \multirow{3}{*}{$\begin{array}{c}\text { Daegu wholesale } \\
\text { market }\end{array}$} & Between groups & 3.335 & 3 & 1.112 & 1.031 & .395 \\
\hline & Within groups & 28.032 & 26 & 1.078 & & \\
\hline & Total & 31.367 & 29 & & & \\
\hline \multirow{3}{*}{ Sentrong Pamilihan } & Between groups & 1.498 & 2 & 749 & 4.331 & .023 \\
\hline & Within groups & 4.669 & 27 & .173 & & \\
\hline & Total & 6.167 & 29 & & & \\
\hline
\end{tabular}

Note: with 0.05 significance level.

ANOVA, analysis of variance.

the more the customers spend their time in Sentrong Pamilihan, the more they spend money. Another one was the time they spent by distance from the market with a 0.023 significance level. It means that the reason why the customers spend a long time in Sentrong Pamilihan was that, the distance of Sentrong Pamilihan was quite far from their location. These cases are mostly present on the trader customers from nearby provinces and cities.

A Cronbach's Alpha with value higher than 0.7 is considered as reliable in comparison with values lower than 0.7. Cronbach's Alpha test in SPSS Statistics was used to identify Cronbach's alpha, thus the reliability of the items of the variables. The researcher would like to know how the customers rate their most recent experiences with products offered by both wholesale markets compared to products that came from other markets. On a scale of 1 to 5 , with 1 being much worse, 2 being somewhat worse, 3 being neutral, 4 being somewhat better, and 5 being much better. The results of the test are presented in 〈Table 5). The research question items of customers' view about product quality by the market have relatively high internal consistency since the alpha coefficient of 
〈Table 5〉 Reliability statistics for customers' view on product quality by market

\begin{tabular}{c|c|c}
\hline Cronbach's alpha & Cronbach's alpha based on standardized items & N of items \\
\hline .941 & .944 & 6 \\
\hline
\end{tabular}

0.941, which indicates a high level of internal consistency or reliability of the test item.

\section{Product Quality}

In the customers' view about product quality by the market (Chart 1 to 6)(〈Figure 3〉), the customers' rate their most recent experiences buying locally

\section{〈Figure 3〉 Customers' view on product quality by market}

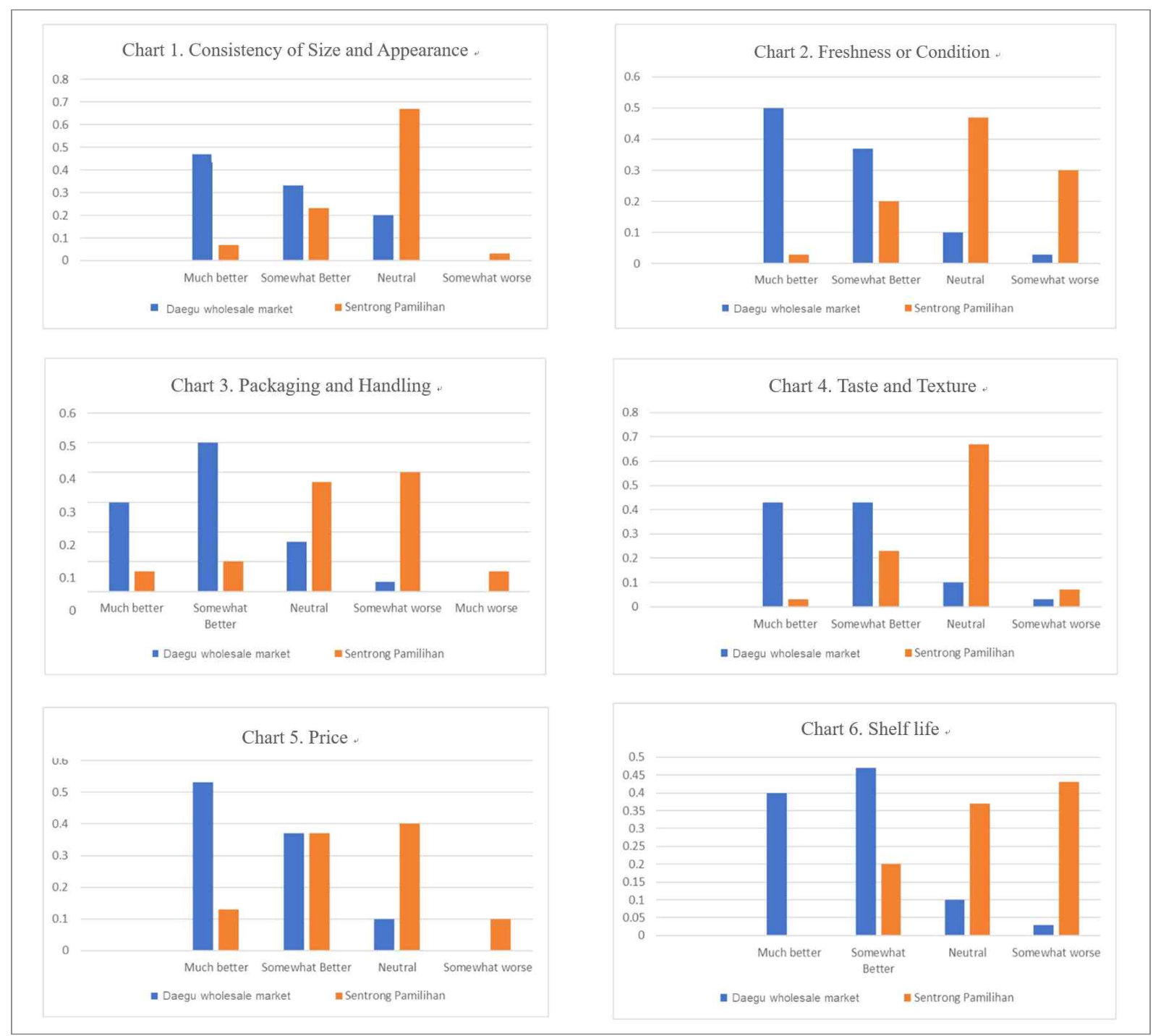


grown fresh fruits and vegetables compared to products from other markets. In general, customers in Daegu wholesale market experienced a more significant percentage of much better service compared to other local markets due to its logistic functions such as availability of storage facilities, transportation, and processing. Also, composition functions such as standardization, grading, finance, risk, and market information provision, helps to ensure that logistics functions are performed smoothly.

On the other hand, the majority of customers in Sentrong Pamilihan experienced somewhat worse when it comes to packaging and handling, and shelf life of products compared from other local markets. These cases are due to shortages and poor conditions and imbalance among market facilities. Sentrong Pamilihan has no available cold storage facility in support of the postharvest activity of agricultural commodities. That is why unsold commodities are disposed of within three (3) days; otherwise, they are pulled out from the trading area or declared "spoiled." In these cases, the Marketer informs the farmer about the unsold commodities/products before they are pulled-out or before selling them at a lower price.

\section{Market Improvement}

Over half of respondents (80\% and 60\%) from both wholesale markets stated that quality was the number one factor influencing them to purchase at the wholesale market, followed by price.

It means that both wholesale markets need to increase the reliability of wholesale market distribution. As consumer preferences for high-quality, safe agricultural products, including eco-friendly produce, tell us that there are small documents to purchase products that are confirmed to be safe, even if they pay a little more. In order for the wholesale market to actively respond to this trend of distribution, it is necessary to deal with high-quality safety agricultural products such as eco-friendly agricultural products, as well as to gain consumer confidence in agricultural products through the wholesale market. By securing confidence in the safety and quality of agricultural products through the wholesale market, the wholesale market itself can become a high-quality brand 
of agricultural products. In order to do this, facilities, safety verification systems, trading systems, packaging, and grading must be standardized effectively.

$60 \%$ of respondents in the Daegu wholesale market said that the parking system was their common inconvenience encountered in the market. That was why there was a need to strengthen the parking management in the market to accommodate the average of 13,000 vehicles every day according to parking data. Currently, this issue is already included in the issues to be solved on their facility modernization project for 2021 to 2023. However, there are still pending issues regarding the budget. It was noted that the quality of offered products in Sentrong Pamilihan was still the most common inconvenience based on $43 \%$ of customers because produce was not correctly graded before being sold. Some vendors are selling their products in a bulky way, including the damaged one, even the market managers encourage the farmers/vendors to be transparent regarding their products, but still, it was a problem. Ideally, the Sentrong Pamilihan should adopt the programs of the Daegu wholesale market with regards to innovative grading and consistent packaging and branding for all product lines. It would help to differentiate products sold at the wholesale farmers' market, increase both demand and prices for farmers, and attract new buyers. Although the Sentrong Pamilihan was managed by the foundation as they have a limited budget, they can still request and propose a project or facilities to the government sector to help them to improve their market facilities.

There are recommendations to strengthen the Suki Relationship5) in the market. In the Philippines, there was a special business relationship referred to as 'suki' in the Filipino language. The Suki relationships (market-exchange partnerships) may develop between two people who agree to become regular customers and suppliers. In the marketplace, customers will regularly buy from certain specific suppliers who will give them, in return, a reduced price, good quality, and, often, credit. 'The buyer can also expect to spend less time at the market because of a diminished need to look for the best quality product at the

5) A Suki Relationship is the relationship between a customer and a trusted supplier. It is a relationship of mutual respect between these two people. If you develop a suki relationship with some vendors, you will get the best prices, the best quality, and a true friend who will look out for you. 
most competitive prices and can also expect unique and personal treatment from the suki. However, it is time to call the attention of farmers producers' concerning seller's poor practices in handling their products to maintain their reputation, quality of their products, and to become more attractive to the buyers. Moreover, for the market operator, continue to evaluate, give training and seminar regarding postharvest management to the farmer producers' and try to seek some funds to the government sector for the possible establishment of postharvest facilities.

\section{CONCLUSION AND RECOMMENDATION}

Based on this study, Daegu wholesale market is more established when it comes to the operation and market facilities because of its long-term experience and the financial support coming from the government compared to Sentrong Pamilihan. However, the researcher set a recommended vital element for both wholesale markets as a guide for future planning, development, and operations:

\section{Daegu Wholesale Market Development Strategy}

\section{1) Strengthening the competitiveness of the wholesale market through logistics efficiency}

The logistics of the wholesale generally have characteristics that are mainly made up of the ground floor. The underground space of the wholesale market is mainly used as a warehouse. In contrast, the second-floor space is used as an office service facility. The auction house, the middle-of-the-line store, and the parking space where the car is located in the wholesale market are all located on the ground floor. In other words, the width of the entire site effectively reflects the congestion of logistics rather than the width of the facility where the duplex is made.

Narrow spaces and underdeveloped distribution facilities are one of the main factors that hinder the revitalization of the Daegu wholesale market which can 
be solved through the modernization of the wholesale market.(Kim, 2007). The necessary foundation for the medium-to-long-term development of the Daegu wholesale market is to create an efficient logistics foundation, which is challenging to promote within the current site. Additional land is needed to reduce the congestion of the wholesale market. By modernizing the market through relocation, a new trading system can be introduced smoothly. The efficient design of the wholesale market import route and the reorganization of the logistics line is necessary.

It is desirable to have sufficient facilities on a separate scale. The existing wholesale market is a wholesale market with facilities focused on auction transactions, and it is not practical to introduce market wholesalers seeking logistics efficiency and distribution independence. In the event of the transfer of the wholesale market, it is practical to secure the necessary facilities based on the introduction of the wholesale market and to expand the wholesale market system by utilizing the facilities in the year.

\section{Sentrong Pamilihan Development Strategies}

Modernization of the wholesale market and the improvement of the trading system should be done in the direction of identifying the characteristics of the primary users of the wholesale market and providing them with maximum convenience.

\section{1) Permanent and year-round facility}

An ideal APWM would include indoor refrigerated and sheltered outdoor selling spaces for farmers with adequate space for farmers and buyers truck circulation and parking plus nearby cold storage facilities that could be used by farmers. With that, the market requires a permanent and year-round facility that can accommodate both vendors and customers.

\section{2) Strong knowledgeable management}

To become a successful wholesale farmers' market, whether operated by public, non-profit, or private entities, they need to have robust and 
knowledgeable management with an understanding of local farmers' and city buyers. The need to achieve the market's dual public mission is by developing and enforcing appropriate rules (including farm inspections) promoting the market to buyers, and conducting supportive educational programs. A mechanism for ensuring farmers and buyers input should be a pivotal element to market management.

\section{3) Grading, packaging, and branding program}

To satisfy the buyers, quality control and branding for products are essential. The buyers can choose fresh foods from numerous sources. The market should have space to conduct farmers and buyerss education as well as assist farmers to be successful in merchandising and displaying products at the market. Farmers will need assistance to make production, handling, and packaging decisions that meet buyers' needs and return the highest profit.

\section{4) Innovative technology}

Important opportunities exist to integrate new technologies in a Daegu wholesale market about their auction market operation and low-temperature warehouse (cold-storage) while markets are among the civilization's oldest public institutions. It needs to go with how modern technology is evolving. Modern technology used by Daegu wholesale market includes real-time information about product availability, quantity, and prices.

It is impossible to rush to more sophisticated practices when the producers are small, the buyers are not organized, and the management skills for running a complex marketing system are not available.

\section{Implications in Daegu Wholesale Market Operation and Manage- ment System for The Development of Sentrong Pamilihan}

\section{1) Daegu wholesale market operation system}

Transaction systems depend highly on the facility type or category and 
arrangement of the relevant wholesale market, and they should be determined in advance when the master plan for constructing and operating the public wholesale market is established. The transaction system for agricultural products is classified globally into the auction system and the wholesaler system, which have compromised or composite systems. An ideal transaction system should be selected generally in consideration of farmers organization type and scale (cooperative association, other corporation), the grade of main production areas for the agricultural products, farmers management scale, distribution of agricultural product markets, general methods of pricing for agricultural products, and farmers opinions.

The transaction practices of the distributors in the existing business zones should be comprehensively considered. The introduction of the auction system needs to build related systems compatible with the auction system. Therefore, it is essential to establish and build an optimum auction method (electronic, manual, mobile, fixed, downward, upward), open auction information, announcement and distribution systems, transportation (in and out of the markets) systems, and pricing systems. An unloading system is required to reduce distribution costs in the market because the unloading costs in the wholesale market are relatively high in auctions. A management and monitoring system is required to regulate behaviours against market orders including unfairness and illegal activities (illegal collusion, price fabrication, false transaction) of participants in transactions. Auctioneers should be strictly managed for optimum pricing and orderly fair transactions in the market by auctions. If the distributors do not perform their tasks properly, it is hard to ensure vitalized markets and competitiveness, and a management system should be built for the performance of their individual tasks (minimum volume of transactions, price payment).

The fees (Marketer's listing fee) or expenses (cost for renting facilities, costs for using facilities, waste disposal) should be paid by participants in the public wholesale markets. It is essential to determine optimum rates of paid expenses. The most critical factor in ensuring reliability in public wholesale market is safe price payment, as it is essential to ensure an explicit price payment system for marketers. 


\section{2) System for Daegu wholesale market management}

There are various types of global management organization. The management organization types are classified into self-management organizations by market participants, management organizations by public officers under establishers (management offices in Korea), management by public institutions (management corporation in Korea), and compromise organizations. The ideal management organization type should be selected in consideration of transaction systems, transaction methods, stage of economic development, features of distribution systems, and the level of distribution participants.

The specific obligations should be given to the management organizations. In general, the essential duties of the public wholesale market management organizations include management of market facilities (repair, maintenance, using and lending facilities), management of participants (unfairness, illegality), orderly markets (transaction order, smooth flow of traffic), management of collection, analysis and propagation of market information, and training of people involved in market activities (distributors, management people).

\section{REFERENCES}

Daegu Metropolitan City. (2020). Daegu metropolitan city northern agricultural and marine products wholesale market. Retrieved from http://www.daegu. go.kr/eco/index.do?menu_id=00001205

Econsult Corporation. (2007). Estimating the economic impact of public markets. New York: Project for Public Spaces. Retrieved from the Project for Public Spaces website: http://www.pps.org

Gombkötő, N. (2018). Comparative analysis of farmers' markets in the Hungarian Transdanubian region. Roczniki (Annals), XX(4), 54-59.

Im, J. (2014). Plan for agricultural product distribution structure improvement. Retrieved from http://ap.fftc.agnet.org/ap_db.php?id=272

Im, J. (2013). Improvement plan of agricultural distribution system. Retrieved from https://ap.fftc.org.tw/article/510

Kim, B. L. (2007). Daegu agricultural and seafood wholesale market activation plan. Retrieved from http://www.krei.re.kr/krei/research.do?key=70\&pageType 
$=010301$

Kuzman, B., Prdić, N., \& Dobraš, Z. (2017). The importance of the wholesale markets for trade in agricultural products. Economics of Agriculture, 64(3), 1177-1190.

Ministry of Agriculture, Food and Rural Affairs [MAFRA]. (2013). 2013 modularization of Korea's development experience: Establishment of the agricultural distribution system: Focusing on public wholesale market construction and management. Sejong, Korea: Ministry of Strategy and Finance .

Oberholtzer, L., \& Grow, S. (2003). Producer-only farmers' markets in the midAtlantic region. Retrieved from https://www.researchgate.net/profile/Lydia _Oberholtzer/publication/237111558_A_Survey_of_Market_Managers/links /004635274e452cee0b000000.pdf

Pabuayon, I. M., Catelo, S. P., Rola, A. C., \& Paris, T. B. (2013). Agricultural policy: Perspectives from the Philippines and other developing countries. Quezon City, Philippines: University of the Philippines Press.

Pabuayon, I. M., Cuevas, A. C., Quilloy, K. P., Delos Reyes, J. A., \& Arrienda, F. Q. (2014). Marketing, trade and distribution issues as they affect food security: Framework and empirical evidence. Paper presented during the Roundtable Discussion On Food Security: Marketing and Postharvest, Quezon City, Philippines.

Prdić, N. (2016). Konkurentska prednost veletržnice kao kanala distribucije. Agroekonomika, Poljoprivredni fakultet univerziteta u Novom Sadu, 72, 51-63. Vlahović, B. (2013). Tržište agroindustrijskih proizvoda, Poljoprivredni fakultet. Novi Sad, Serbia: Univerzitet u NovomSadu. p. 261.

논문 접수일: 2020.10.20. 수정논문 접수일: 2020.11.15. 게재 확정일: 2020.11.28. 